\title{
RENAL TOXICITY OF ANAESTHETICS: WITH SPECIFIC REFER NCE TO THE NEPHROTOXICITY OF METHOXYFLURANE
}

\author{
RTCHARD I. MAZZE, M.D. ${ }^{\circ}$ \\ MiChaEL J. Cousins, M.B., B.S., F.F.A.R.A.C.S., F.F.A.R.C.s. $\uparrow$
}

Toxic NEPHRopathy is defined as any adverse functional or structural change in the kidney due to the effect of a chemical or biological product which is inhaled, ingested, injected or absorbed, or which yields toxic metabolites with an identifiable effect on the kidneys. ${ }^{1}$ In general, drugs and biologically active compounds reach their site of action by way of the circulatory system. The kidneys, together weighing only 0.4 per cent of total body weight, receive 25 per cent of resting cardiac output. Thus, they are rapidly exposed to peak concentrations of chemical substances even those which are only transiently circulating. The kidney has a high metabolic rate and therefore is susceptible to agents producing cellular anoxia. A vascular network serves as a countercurrent mechanism resulting in hypertonicity of the interstitium of the renal papillae. Because of this mechanism, medullary concentration of specific compounds, as well as osmotically active solutes, is possible to a degree not found in other interstitial tissues of the body.

Compounds excreted by the kidneys fall into three categories: (1) those which undergo filtration alone and are progressively concentrated along the luminal cell surface of the nephron, as salt and water are continuously absorbed; (2) those which undergo tubular reabsorption and require penetration of the cell, interaction with carrier systems and local concentration at the capillary-cell border; and (3) those which are actively secreted and involve enzyme systems, carriers, cell energetics and high concentration at the luminal surface, further enhanced by concentration of the urine. ${ }^{1}$ Intravenous agents used for producing general anaesthesia, such as barbiturates, narcotics and tranquilizers and their metabolic products are known to be primarily excreted by the kidney. Inhalation agents, once thought to be almost totally excreted by the lungs are now known to undergo extensive biodegradation, ${ }^{2}$ with renal excretion the primary method of elimination of metabolites from the body. ${ }^{3,4}$ Though the exact method by which the kidney excretes each anaesthetic agent and its metabolites is not known there appears to be ample exposure of the kidney to these substances to produce toxicity.

In the broadest sense all general anaesthetics are nephrotoxins. They are not

Departments of Anaesthesia, Stanford University School of Medicine, Stanford, California 94305, and Veterans Administration Hospital, Palo Alto, California 94304.

*Associate Professor of Anesthesiology.

†Assistant Professor of Anesthesiology.

Presented at the Symposium on The Acute and Chronic Toxicity of Anaesthetic Agents, Canadian Anaesthetists' Society Meeting, June 18, 1972, Halifax, Nova Scotia. D1Al.

Supported in part by VA Hospital, Palo Alto, CA and Public Health Service Grants GM-18514-

Canad. Anaesth. Soc. J., vol. 20, no. 1, January 1973 
alone among therapeutic agents in this category; antibiotics, such as sulfonamides, kanamycin and gentamicin and analgesics, such as salicylates, phenacetin and phenylbutazone are other frequently administered drugs with nephrotoxic potential. The magnitude of intraoperative changes in renal function are shown in Table I. The pattern of response is one of generalized depression of all measured function; urine flow, glomerular filtration rate (GFR), renal blood flow (RBF) and electrolyte excretion. These changes appear to be largely secondary to the effect of anaesthetics on the cardiovascular, sympathetic, and endocrine systems rather than on the kidneys themselves. Renal blood flow and GFR usually return to normal within a few hours after the termination of surgery, although the ability to promptly excrete a water load may be impaired for several days. ${ }^{14}$

The persistence of abnormalities in renal function, such that the kidneys are not able to vary urine volume and content appropriately in response to homeostatic needs, occasionally occurs. This condition can vary from one of mild impairment to anuric or polyuric renal failure. Renal failure is rarely due to the choice of anaesthetic agent alone; rather, it is more likely due to a combination of factors, of which the anaesthetic agent is a minor one. The nature and duration of the surgical procedure, the prior existence of renal and/or cardiovascular disease and the preoperative, intraoperative, and postoperative management of fluid and electrolyte balance are the major factors involved in surgical renal failure. Methoxyflurane appears to be an exception to this rule having a direct depressant effect upon renal function, particularly the kidney's ability to conserve water. ${ }^{15-17}$ These effects will be discussed below.

In the healthy patient undergoing a relatively minor operation, any well administered anaesthetic and virtually any fluid regimen, will be tolerated without difficulty. However, in other patients, anaesthesia and surgery may carry markedly increased risks of postoperative renal failure. Patients undergoing surgery of the aorta, those having procedures in which large volumes of blood may be transfused, older patients having lengthy or extensive surgical procedures, patients with preexisting cardiac or renal disease, patients with obstetrical complications such as abruptio placentae, and patients who have suffered major trauma all face an increased likelihood of such renal injury. To minimize this danger, these patients must be carefully prepared with special attention to the renal and cardiovascular systems. Preoperative, intraoperative, and postoperative Huid, acid-base, and electrolyte balance must be monitored and corrections made when necessary. It is particularly important to adjust fluid balance throughout the operation itself. To do this it is necessary to introduce an indwelling urethral catheter prior to surgery to measure urine flow rate and to replace measured fluid volume and estimated insensible losses with a physiological salt solution. The use of an osmotic diuretic, such as mannitol, may be necessary to maintain urine flow rate at $60-100 \mathrm{ml} /$ hour during and after surgery if hydration alone is not adequate for this purpose. ${ }^{18}$ Finally, an anaesthetic method and agent should be chosen which produces minimal depression of renal function. Though it appears that all general anaesthetic agents produce some depression of function, neurolept analgesia may be the least disadvantageous ${ }^{13}$ due to its alpha adrenergic blocking effect. Regional nerve block, low spinal and epidural anaesthesia ${ }^{18 a}$ produce clinically insignificant intra- 
operative depression of renal function and should be employed when the surgical procedure permits.

\section{METHOXYfluRANE INDUCED NEPhROTOXICITY}

The possibility that there might be a specific anaesthetic induced nephrotoxicity was first reported by Crandell et al. ${ }^{15}$ in 1966 . They reported that renal insufficiency with high urine volume occurred in 13 of 41 patients who received methoxyflurane for abdominal surgery. Urine volume was 2.5-4.0 liter/day with a negative fluid balance, elevation of serum sodium, serum osmalality, and blood urea nitrogen, and a relatively fixed urine osmolality close to that of serum. Patients were unable to concentrate urine despite fluid deprivation and vasopressin administration, suggesting that the difficulty was of renal origin and not due to anti-diuretic hormone (ADH) deficiency. Impairment lasted from 10 to 20 days in most patients, but in three, abnormalities persisted for longer than one year. ${ }^{17}$ Pezzi et al. ${ }^{19}$ in a brief report had noted a similar syndrome in 16 per cent of 123 patients undergoing abdominal surgery with methoxyflurane. However, all of their patients suffered major medical or surgical complications which they acknowledged might have significantly contributed to the observed renal difficulties.

In the five years since the publications of Crandell et al. ${ }^{15}$ and Pezzi et al. ${ }^{19}$ only a few case reports ${ }^{20-23}$ of high output renal insufficiency associated with methoxyflurane administration had been reported until the controlled, randomized, prospective, clinical evaluation from our laboratory. ${ }^{16}$ To avoid difficulties of interpretation, inherent in studies in which multiple drugs have been employed, methoxyflurane was administered in a manner somewhat different from that which is customary in clinical practice. Narcotic premedication, barbiturates and nitrous oxide were omitted. It is not clear if this influenced results since these adjuncts were administered in previously reported cases of methoxyflurane nephrotoxicity. ${ }^{20-23}$ In our study, curare was used for muscle relaxation and anaesthetic depth never appeared excessive. In five patients, end-tidal alveolar methoxyflurane concentrations were determined during the third hour of anaesthesia. Values ranged from 0.6 to 1.9 MAC (Mean 1.4), well within the expected clinical range.

Our results agreed with those of Crandell et al. ${ }^{15}$ and went even further: abnormalities were found in all cases. Patients exhibited polyuria unresponsive to ADH administration, marked weight loss, delayed return of preoperative concentrating ability, hypernatraemia, serum hyperosmolality, elevated BUN and serum creatinine, increased serum uric acid and a decrease in uric acid clearance. In six of the twelve patients studied these abnormalities complicated the patient's postoperative management. Nephrotoxicity was not permanent in any of the patients in our series although Hollenberg ${ }^{25}$ has reported permanent renal failure in three patients and we have seen two additional cases of permanent renal failure following methoxyflurane anaesthesia.

The site of the renal lesion was not specifically determined. The elevation in serum uric acid level associated with a decrease in uric acid clearance, and the absent or decreased response to exogenous vasopressin suggested a lesion of the distal convoluted tubule or collecting duct. An alternative explanation was that washout of medullary sodium concentration occurred preventing development of an osmotic gradient necessary for the reabsorption of water. 


\section{MEAN SERUM $\mathrm{F}^{-}$}

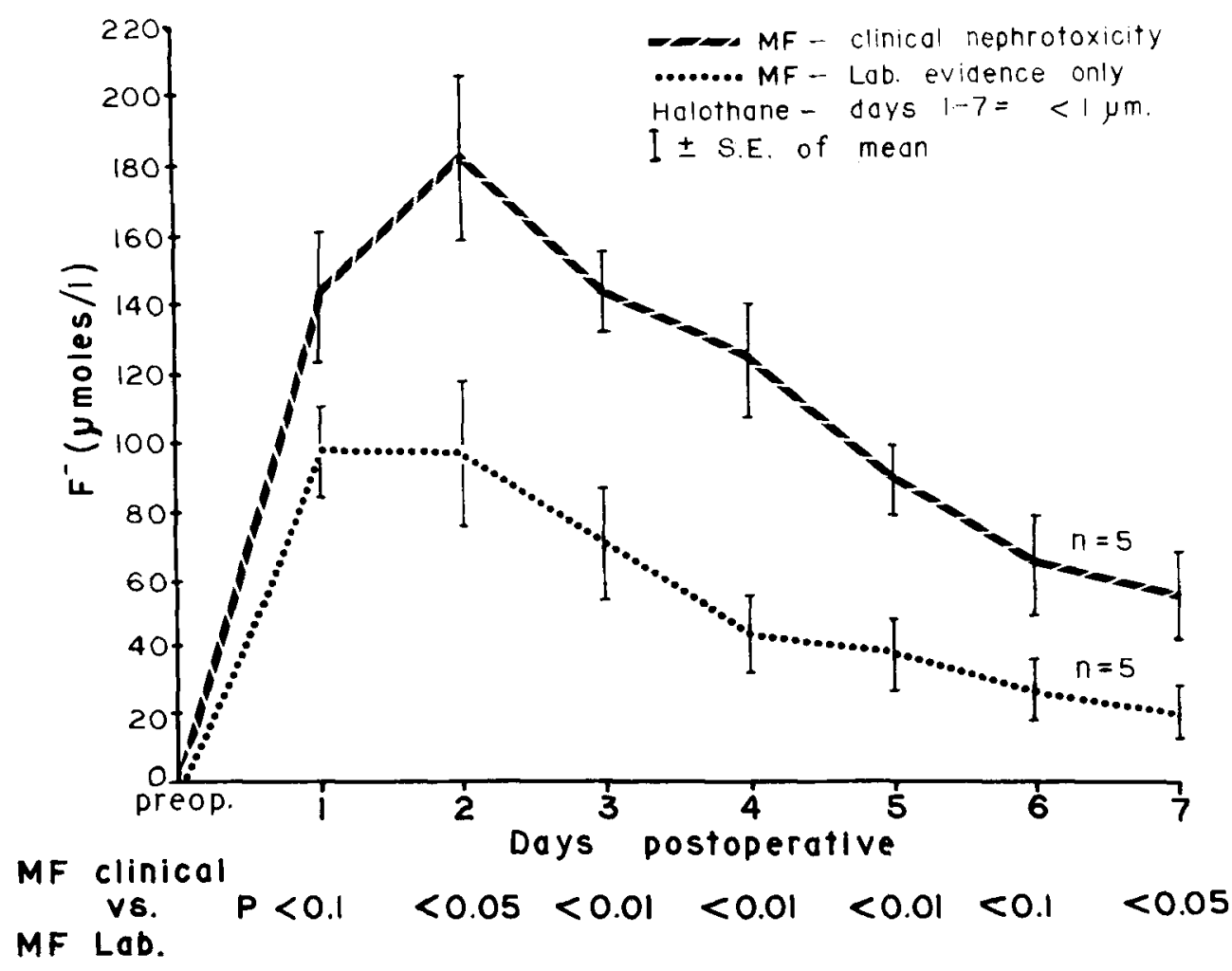

Ficune 1. Mean daily serum inorganic fluoride concentrations. Patients anaesthetized with methoxyflurane were divided into two sub-groups, those with laboratory abnormalities in renal function and those with laboratory abnormalities as well as clinically evident nephrotoxicity. Preoperative inorganic fluoride concentration was approximately $1 \mu \mathrm{M} / 1$ in all patients, with no change noted following halothane anaesthesia. (Reproduced with permission of Anesthesiology ${ }^{4}$ )

\section{Aettology of NePhRotoxicity}

It had been suggested by Taves $e t$ al. ${ }^{28}$ that one of the metabolites of methoxyflurane, inorganic fluoride, was related to its nephrotoxicity. They reported increased concentrations of inorganic fluoride in the serum and urine of a patient who had renal dysfunction following methoxyflurane anaesthesia. About the same time Frascino et al. ${ }^{27}$ noted oxalic acid crystals in renal biopsy specimens and increased urinary oxalic acid excretion in several patients with postoperative renal insufficiency after methoxyflurane anaesthesia.

These findings prompted us to measure inorganic fluoride concentration and oxalic acid excretion in serum and urine samples obtained from patients at the time of our initial investigation and kept in frozen storage. ${ }^{4}$ These determinations revealed increased concentrations of inorganic fluoride in all patients anaesthetized with methoxyflurane with the highest levels reported in those patients with the greatest impairment of renal function (Figure 1). Five patients with clinically 


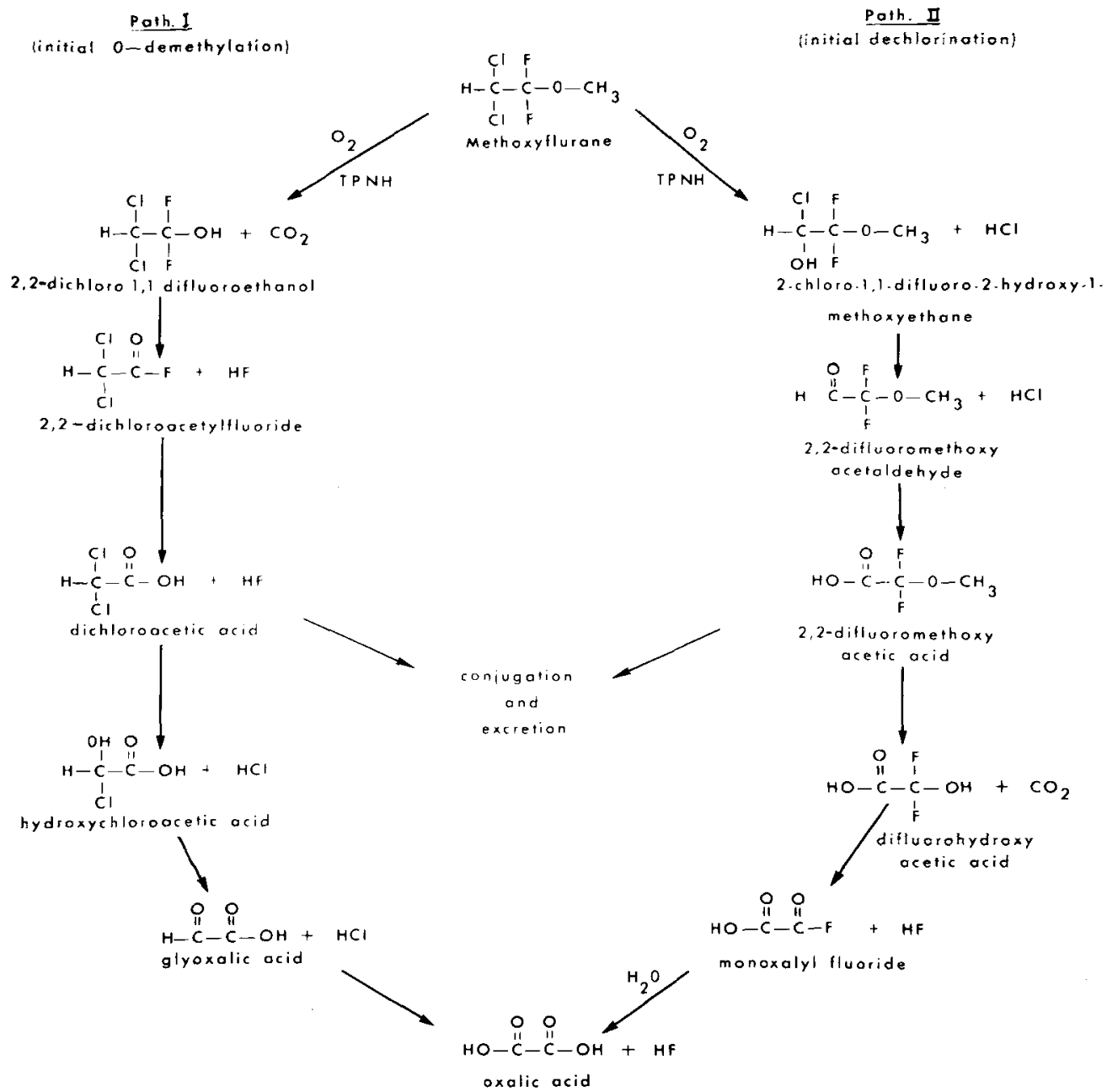

Ficure 2. Metabolic pathways for the metabolism of methoxyflurane. Pathway I. Methoxyflurane is $\mathrm{O}$-demethylated in the liver producing 2,2-dichloracetylfuoride and a molecule of hydrogen fluoride. Acetyl fluoride is further hydrolized to dichloracetic acid liberating another molecule of hydrogen fluoride. A portion of the dichloracetic acid is excreted in the urine while a second part is oxidatively dechlorinated to glyoxalic acid. The latter is enzymatically oxidized to oxalic acid. Pathway II. Methoxyflurane is enzymatically dechlorinated to 2,2-difluoromethoxyacetic acid. A portion is excreted in the urine and a second part $\mathbf{O}$-demethylated in the liver. Subsequent dehydrofluorination and hydrolysis result in oxalic acid formation.

evident nephrotoxicity had a mean peak serum inorganic fluoride level (190.4 \pm $20.9 \mu \mathrm{M} / 1$ ) significantly higher than that measured in patients with abnormalities in laboratory tests only $(105.8 \pm 17.0 \mu \mathrm{M} / 1)$. Similarly, patients with clinically evident nephrotoxicity had a mean peak oxalic acid excretion $(286.8 \pm 39.3 \mathrm{mg} / 24$ hours) significantly greater than patients with laboratory abnormalities only ( 130.6 $\pm 51.4 \mathrm{mg} / 24$ hours $)$.

To explain the increases in inorganic fluoride concentration and oxalic acid excretion following methoxyflurane anaesthesia we proposed two complimentary metabolic routes for biotransformation of methoxyflurane (Figure 2 ). These were 
based on our findings, ${ }^{4}$ other metabolites identified previously ${ }^{2,3,26-28}$ and enzyme systems known to exist in man.

Both inorganic fluoride and oxalic acid have nephrotoxic potential with the former most likely the primary nephrotoxin. The most compelling arguments for this concept were the clinical correlation of renal dysfunction and increased serum inorganic fluoride concentration noted above; the known potent inhibitory effects of inorganic fluoride on many enzyme systems including those thought to be involved in the action of antidiuretic hormone, ${ }^{29}$ and the occurrence of polyuric renal insufficiency in rats fed a diet high in sodium fluoride. ${ }^{30}$ From this evidence, it appeared that the renal toxicity of methoxyflurane was directly related to the dose of methoxyflurane and its metabolism to inorganic fluoride.

Still, an explanation had to be sought for the high incidence of renal dysfunction in our study ${ }^{16}$ and that of Crandell et al. ${ }^{15}$ Though there were no clinical signs that our patients were too deeply anaesthetized, it is likely that total methoxyflurane dosage was high. This probably resulted from the use of an inhalation induction and omission of barbiturates, narcotics and nitrous oxide in operative procedures lasting more than four hours. Supporting the concept of a dose related lesion, we found no changes in renal function in a randomized prospective study of ten patients anaesthetized with small doses of methoxyflurane (mean arterial concentration $7.8 \pm 1.0 \mathrm{mg} / 100 \mathrm{ml}$; anaesthesia time, 2 hours, 13 minutes) for operations involving cardiopulmonary bypass. ${ }^{31}$ Results were compared with those obtained in a control group of ten patients anaesthetized with morphine-halothane. Mean peak serum inorganic fluoride concentration, although increased from $1.7 \pm 0.3 \mu \mathrm{M} / 1$ to $45.7 \pm 4.2 \mu \mathrm{M} / 1$, was only $25-50$ per cent of that previously found to produce renal dysfunction. These findings supported the hypothesis that renal dysfunction associated with methoxyflurane anaesthesia was dose-related.

At that time, a direct cause-effect relationship of methoxyflurane administration and renal dysfunction was still not conclusively established. This was in part due to the absence of nephrotoxicity in animal experiments, several of which were specifically designed to evaluate the renal effects of methoxyflurane. ${ }^{32,33,34}$ After screening five different strains of rats we determined that only one, the Fischer 344 strain, developed nephrotoxicity following methoxyflurane administration. ${ }^{35}$ As in man, the syndrome was characterized by dose-related vasopressin-resistant polyuria (Figure 3), hypernatraemia, serum hyperosmolality and increased serum urea nitrogen and inorganic fluoride concentrations. ${ }^{36}$ Urinary sodium, potassium, osmolality and urea nitrogen concentrations were decreased in proportion to the administered methoxyflurane dose. Light and electron microscopic changes were most prominent in the proximal convoluted tubules and were also dose-related (Figure 4). ${ }^{36 u}$ Injection of inorganic fluoride produced changes in renal function and histology similar to those seen following methoxyflurane administration. On the contrary, oxalic acid injection in a dose similar to that resulting from methoxyflurane metabolism did not result in abnormalities of renal function or histology. ${ }^{37}$

In other studies we have shown that enzyme induction following phenobarbital administration resulted in increased methoxyflurane metabolism and a more severe renal lesion. ${ }^{37}$ Also, concurrent administration of methoxyflurane and the aminoglycoside antibiotic, gentamicin, produced greater nephrotoxicity than expected from 


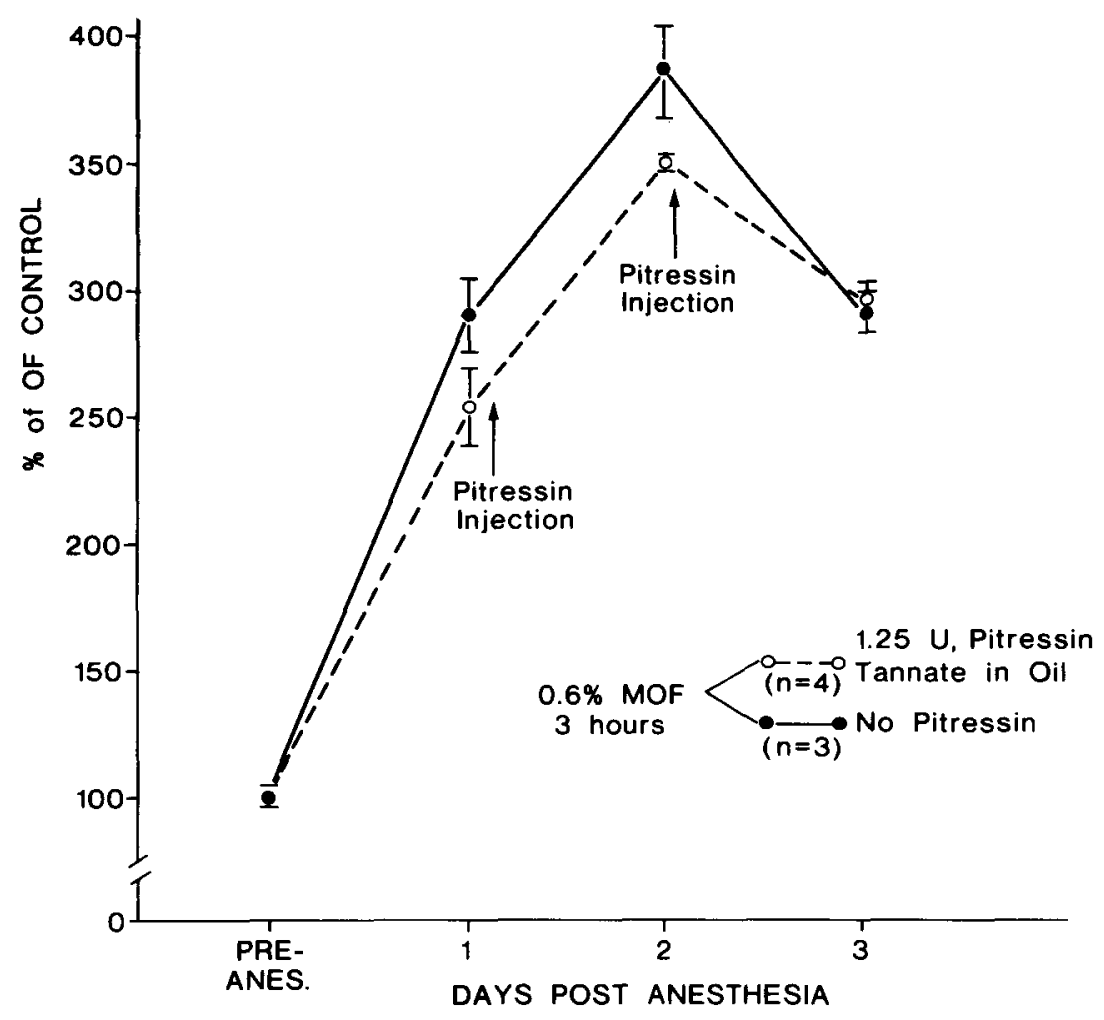

FIGURE 3. Fischer 344 rats were anaesthetized with 0.6 per cent methoxyflurane for three hours. Pitressin administration had no effect on the polyuria produced by this treatment. Abbreviation: SEM, standard error of mean (reproduced with permission of Anesthesiology).36

either drug alone. ${ }^{38}$ This response is similar to the additive nephrotoxicity we observed in patients receiving both methoxyflurane and gentamicin. ${ }^{39}$

Finally, in our most recent prospective clinical study of general surgical patients in which anaesthetic adjuncts were administered, we again correlated nephrotoxicity with methoxyflurane dosage and serum inorganic fluoride concentration. Twenty-six patients having elective surgical procedures were divided into four groups: Group I received MOF, 0.5 MAC; Group II, MOF, 1.0 MAC; Group III, MOF, 1.5 MAC; and Group IV, halothane 1-1.5 MAC. Total anaesthetic dosage was determined by multiplying end-alveolar methoxyflurane concentration times duration of anaesthesia (MAC Hours).

The onset of mild toxicity occurred at approximately 2.5 MAC Hours, which corresponded to a serum inorganic fluoride level of 50-60 $\mu \mathrm{M} / 1$. At 5.0 MAC Hours and above ( serum inorganic fluoride level, $>90 \mu \mathrm{M} / 1$ ), increased toxicity was seen, which in some cases was quite marked. These clinical studies and the animal work cited above ${ }^{36,37}$ conclusively prove that the renal lesion associated with methoxy- 

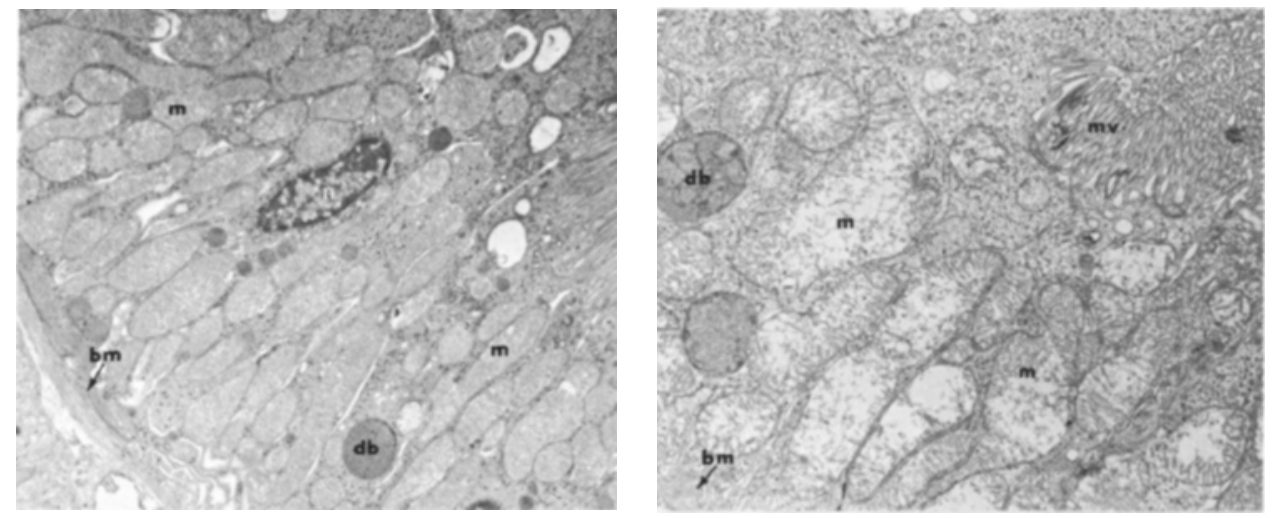

FIGURE 4. Electron photomicrographs of rat proximal convoluted tubule cells: (left) control section, $\times 4,000$; (right) 24 hours following methoxyflurane anaesthesia, 0.75 per cent, 6 hours, $\times 6,000$. Note the normal cigar shaped mitochondria $(\mathrm{m})$ in the control section and the markedly swollen and distorted mitochondria in the section from the anaesthetized rat. In the latter section there is disruption of christae and in some cases rupture of the organelles. Additional abbreviations: bm, basement membrane; $\mathrm{db}$, dense body; n, nucleus; mv, microvilli. (Electron photomicrographs supplied by courtesy of Dr. Jon C. Kosek.)

flurane administration is dose-related and dependent upon the amount of inorganic fluoride produced from biodegradation of the anaesthetic (Figure 5).

Though low dose methoxyflurane anaesthesia usually produces only moderate increases in inorganic fluoride concentration, which are not associated with renal insufficiency, ${ }^{31}$ the safety of this technique is probably not absolute. We have observed individual variation in methoxyflurane metabolism from the same administered dose, resulting in markedly different serum inorganic fluoride concentrations. ${ }^{40}$ There also appears to be marked variation in the susceptibility of different individuals to fluoride as a nephrotoxin. ${ }^{40}$ In addition, several questions remain unanswered: (1) Will enzyme induction in man due to exposure to various chemical substances such as barbiturates, tranquilizers, insecticides, aerosol sprays or methoxyflurane itself exacerbate renal toxicity, as it does in Fischer 344 rats? (2) Does repeat administration of methoxyflurane impose an increased risk of toxicity due to enzyme induction and residual levels of inorganic fluoride? (3) What is the interaction of methoxyflurane with other potentially nephrotoxic therapeutic agents? It is known that the nephrotoxicity of methoxyflurane plus tetracycline ${ }^{21}$ and methoxyflurane plus gentamicin are additive. ${ }^{38,29}$ Do other therapeutic agents also cause additive nephrotoxicity? It is a matter of great concern in the use of methoxyflurane that it cannot be predicted if a patient will need a nephrotoxic antibiotic in the early postoperative period. For these reasons, it is impossible to say that administration of low dose methoxyflurane anaesthesia will not result in nephrotoxicity.

If methoxyflurane is to be administered at all, we believe its use should be limited to special situations when low dosage can be attained, such as obstetrical analgesia, open-heart surgery ${ }^{31}$ and surgical procedures of short duration. We recommend two hours as the upper time limit for surgical anaesthesia with methoxyflurane. 


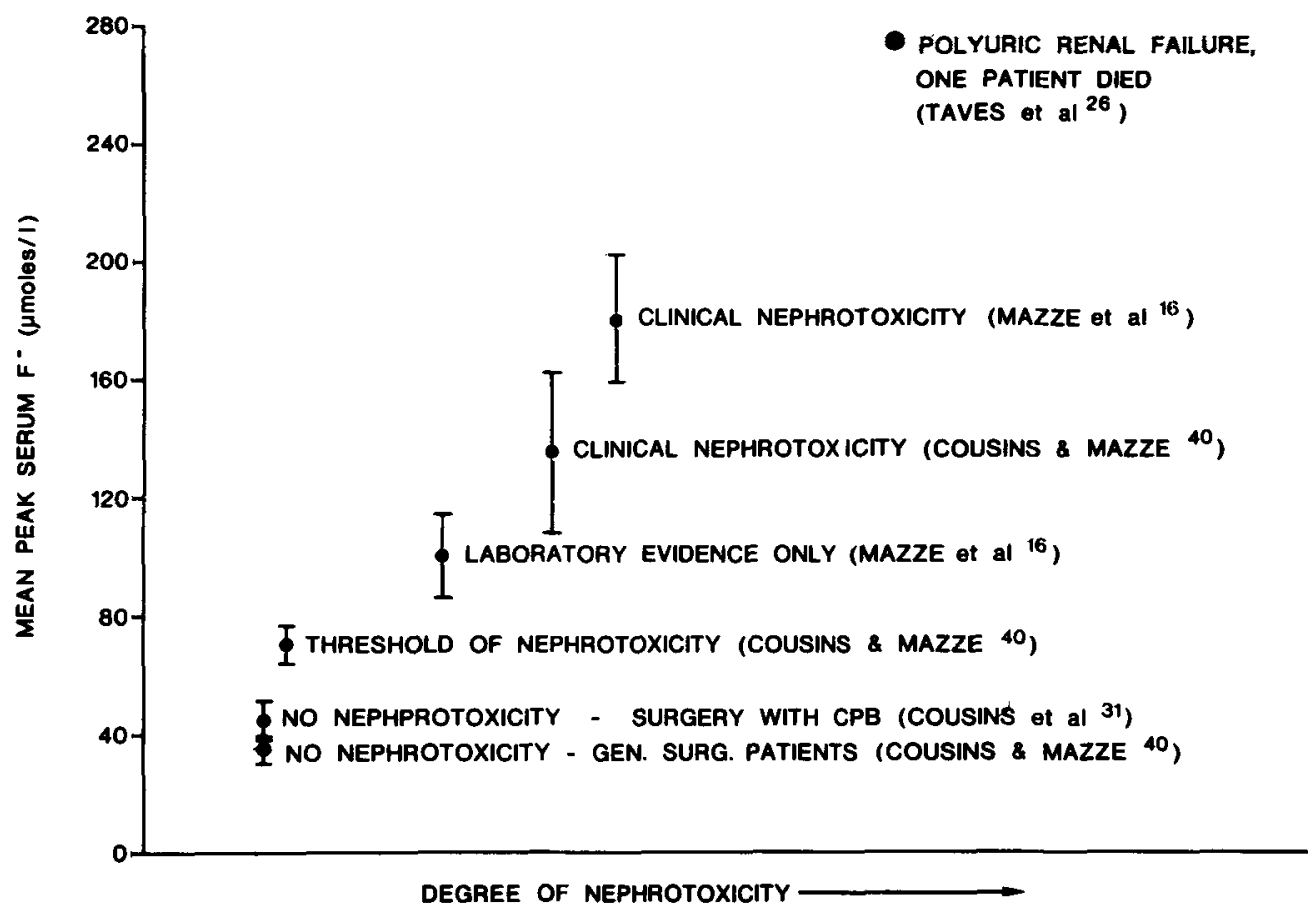

Figure 5. Data from clinical studies ${ }^{16,26,31,40}$ correlating mean peak serum inorganic fluoride concentration and nephrotoxicity. Abbreviation: $\mathrm{CPB}$, cardiopulmonary bypass.

Though it is possible to maintain anaesthesia at a depth of less than one MAC when nitrous oxide, barbiturates, narcotics and muscle relaxants are employed, in the usual clinical setting where partition coefficients and end-alveolar and arterial methoxyflurane concentrations are not determined, the anaesthetist can never be sure of exact anaesthetic dosage. Therefore, the most practical way to remain below a total methoxyflurane dose of 2.5 MAC Hours is to limit anaesthetic duration. It should be emphasized that even with a time limit of two hours a gradual decrease in delivered methoxyflurane concentration is necessary so that the lowest possible alveolar concentration is maintained. In fact, if high concentrations are administered it is quite possible to deliver a nephrotoxic dose of methoxyflurane in two hours. It should be obvious that the use of high concentrations of methoxyflurane to reduce blood pressure or to obtain muscle relaxation is contraindicated. Similarly, danger of overdosage is inherent in the use of inaccurate, in-circle vaporizers, which are not temperature or flow compensated. Patients with renal disease, those having operations on the genitourinary tract or where renal complications frequently represent a postoperative hazard, also should not be anaesthetized with methoxyflurane.

Finally, one should consider whether methoxyflurane should be administered to any patient requiring prolonged, postoperative, intravenous alimentation. The overwhelming majority of case reports of methoxyflurane nephrotoxicity and most of the patients in our clinical studies have required prolonged intravenous feeding. 
In these cases there frequently has been a period of dehydration, following which marked deterioration of the clinical course occurred. It is possible that the reduced formation of glomerular filtrate associated with dehydration may actually intensify the renal lesion of methoxyflurane. At the same time, severe nephrotoxicity is rare in patients with free access to oral fluids. This would suggest that the drug should be avoided when more than a day or two of intravenous feeding is anticipated. We believe these restrictions on the use of methoxyflurane would greatly reduce the incidence of nephrotoxicity following its administration.

\section{RÉSUMÉ}

Une néphropathie toxique est définie comme toute perturbation fonctionnelle ou structurale du rein due aux effets d'un agent chimique ou biologique inhalé, ingéré, infecté ou absorbé, ou d'un agent qui cède des métabolites toxiques ayant un effet identifiable sur les reins. En général, les médicaments et les composés actifs biologiquement atteignent leur site daction par voie sanguine circulatoire. Les reins, quoique ne représentant que 0.4 pour cent du poids corporel total, reçoivent 25 pour cent du débit cardiaque au repos. Alors, ils sont rapidement exposés aux concentrations maximales des substances chimiques, même de celles qui ne sont dans la circulation que de façon transitoire. Le rein, a cause de son métabolisme élevé est très sensible aux agents produisant de l'anoxie cellulaire. Un réseau vasculaire servant de mécanisme de "contre-courant" amène une hypertonicité du milieu interstitiel des papilles rénales.

A cause de ce mécanisme, certains composés spécifiques et certains solutés actifs osmotiquement peuvent atteindre une concentration médullaire n'existant pas dans les autres tissus interstitiels de l'organisme.

Les composés excrétés par le rein se classifient ainsi:

(1) Ceux qui ne subissent qu'une filtration et qui sont concentrés progressivement le long de la surface luminale des cellules du néphron, et qui, comme le sel et l'eau sont réabsorbés continuellement ;

(2) Ceux qui subissent une réabsorption tubulaire et nécessitent une pénétration cellulaire, une inter réaction avec les systèmes de transfert et une concentration locale au niveau des cellules près des capillaires.

(3) Ceux qui sont secrétés activement et ont besoin des systèmes enzymatiques, des systèmes de transport, des cellules énergétiques et d'une concentration élevée à la surface luminale des cellules. Les agents à administration intra-veineuse pour produire l'anesthésie générale tels que les barbituriques, les narcotiques, les tranquilisants et leurs métabolites sont connus pour être excrétés d'abord par le rein. Les agents d'inhalation, autrefois connus pour être excrétés presque totalement par les poumons, subissent une biodégradation extensive avec excrétion rénale comme premier moyen d'élimination de leurs métabolites, de l'organisme. La façon par laquelle le rein élimine chacun des agents anesthésiques n’est pas connue, mais il semble y avoir exposition suffisante pour produire une toxicité.

Dans leur sens le plus large, tous les anesthésiques généraux sont des néphrotoxines. Plusieurs agents thérapeutiques entrent dans cette catégorie : les anti- 
biotiques, les sulfamidés, la kanamycine et la tétracycline, et les analgésiques tels que salycilates, phénacétine et phenylbutazone sont d'autres agents fréquemment administrés et ayant un potentiel néphrotoxique.

L'ampleur des changements de la fonction rénale pendant lopération sont démontrés dans le tableau I.

Le tableau de la réponse rénale en est un de dépression généralisée de toutes les fonctions mesurées : flot urinaire, taux de filtration glomérulaire, flot sanguin rénal et excrétion des électrolytes. Ces changements semblent être secondaires aux effets des agents anesthésiques sur les systèmes cardio-vasculaire, sympathique et endocrinien plutôt que sur les reins eux-mêmes. Le flot sanguin rénal et le taux de filtration glomérulaire reviennent ordinairement à la normale en dedans de quelques heures après la fin de la chirurgie, bien que la capacité d'excréter rapidement une charge d'eau puisse être perturbée pendant plusieurs jours. On retrouve occasionnellement des anomalies persistantes de la fonction rénale telles que le rein n'est pas capable de varier le volume urinaire et son contenu de façon appropriée en réponse à des besoins homéostatiques. Cette anomalie peut varier d'un trouble léger à une défaillance rénale anurique au polyurique. La défaillance rénale est rarement due au choix de l'agent anesthésique seul, mais plutôt à une combinaison de facteurs, parmi lesquels l'agent est un facteur mineur. La nature et la durée de l'opération, l'état cardiovasculaire et rénal antérieur, l'équilibre liquidien et électrolytique avant, pendant et après l'opération sont les principaux facteurs à considérer lors des défaillances rénales. Le méthoxyflurane semble être une exception à cette règle et a un effet dépresseur direct sur la fonction rénale, particulièrement la capacité du rein de conserver l'eau ces effets seront discutés plus loin.

Pour un patient en bonne santé subissant une opération relavivement mineure, tout agent anesthésique bien administré et tout régime liquidien seront bien tolérés. Cependant chez d'autres patients, l'anesthésie et la chirurgie peuvent augmenter considérablement les risques de défaillance rénale en période post opératoire. Les patients subissant une chirurgie de l'aorte, recevant des transfusions massives, les patients âgés subissant des interventions prolongées et extensives, ceux présentant des pathologies rénales ou cardiques pré-existantes, les patients présentant des cations obstétricales telles qu'un placenta praevia, et les patients ayant subi un traumatisme sévère tous sont susceptibles de présenter une atteinte rénale. Pour minimiser ce danger, ces patients doivent être préparés avec soin avec une attention spéciale aux systèmes rénal et cardiovasculaire.

On doit surveilleir l'équilibre liquidien, électrolytique et acido-basique avant, pendant et après lopération et le corriger au besoin. Il est particulièrement important de controler la balance liquidienne pendant l'opération, il est donc nécessaire d'introduire un cathéter vésical avant la chirurgie pour mesurer le flot urinaire et de remplacer les liquides urinés et les pertes insensibles par du sérum physiologique. Si l'hydratation seule ne suffit pas, il peut être nécessaire d'employer un diurétique, genre mannitol, pour maintenir un flot urinaire de 60 à $100 \mathrm{mls}$ par heure pendant et après l'intervention. Enfin on doit choisir un agent anesthésique et une méthode d'anesthésie amenant le moins de dépression possible de la fonction rénale. Tous les agents semblent produire un certain degré de dépression de la fonction rénale, 
cependant la neuroleptanalgésie à cause de ses effets bloqueurs $\mathrm{x}$ adrénergiques peut être la moins désavantageuse, tandis que le méthoxyflurane doit ètre évité chez les patients présentant un risque de défaillance rénale en période postopératoire.

\section{Méthoxyflurane et disfonction rénale}

Crandell et associés en 1966, furent les premiers à rapporter une néphrotoxicité spécifique aux agents anesthésiques. Ils ont rapporté de l'insuffisance rénale avec débit urinaire élevé chez 11 de 41 patients anesthésiés au méthoxyflurane pour des interventions abdominales. Ils notèrent chez ces patients un volume urinaire de 2.5 à $4 \mathrm{~L}$ /jour avec une balance liquidienne négative, une élévation du sodium sérique, de l'osmolarité sérique, de l'urée sanguine et une osmolarité urinaire relativement fixe voisine de celle de sérum. Ces patients étaient incapables de concentrer malgré une déprivation de liquide et l'administration de pitressine; ceci suggérant que la difficulté était d'origine rénale et non due à une déficience d'ADH. Les perturbations rénales durèrent de 10 à 20 jours chez la plupart des patients, mais chez trois patients, les anomalies persistèrent pendant plus d'un an. Pezzi et associés avaient noté antérieurement un syndrome similaire chez 16 pour cent des 123 patients subissant une chirurgie abdominale sous anesthésie au méthoxyflurane. Cependant tous leurs patients avaient souffert de complications médicales ou chirurgicales majeures ayant pu contribué aux problèmes rénaux observés.

Antérieurement lors d'une étude des fonctions hépatiques et rénales, North et Stephen avaient noté une élévation de l'urée lors d'anesthésie au méthoxyflurane, mais les autres éléments de défaillance rénale à débit élevé étaient absents. Paddock et associés ont observé le développement de défaillance rénale chez trois de leurs patients anesthésiés au méthoxyflurane. L'examen pathologique des reins de 2 patients morts de ce syndrome a montré une néphrosclérose artérielle et artériolaire médérée avec la présence de crystaux d'oxolate de calcium dans les tubules. L'examen additionnel de coupes de rein lors de 200 autopsies et l'étude de la fonction rénale chez $\mathbf{4 0}$ sujets mâles normaux ayant reçu une anesthésie au méthoxyflurane n'ont pu démontrer une association de cet agent anesthésique avec une lésion rénale chez des patients normaux.

Dans les 5 années suivant la publication de Crandell et Pezzi, on n'a rapporté que quelques cas d'insuffisance rénale à débit élevé associés à l'administration de méthoxyflurane jusqu'à l'évaluation clinique de Mazze et associés. Dans cette étude, le méthoxyflurane a été administré de façon différente, en ce sens que la prémédication fut omise, un barbiturique non employé pour l'induction et le protoxyde d'azote non utilisé dans le mélange gazeux pour le maintien de l'anesthésie. Leurs résultats concordent avec ceux de Crandell et ass. et vont même plus loin: on a rencontré les anomalies rénales chez tous les patients. Mazze et associés ont noté une polyurie ne répondant pas à l'administration d'ADH, une perte de poids marqué, un retard dans le retour au niveau pré-opératoire de la capacité rénale de concentrer, une hypernatrémie, une hyperosmolarité sérique, l'urée et la créatinine élevées, une augmentation de l'acide urique dans le sérum des patients anesthésiés au fluothane n'a répondu de cette façon. Six patients sur 12 étudiés présentent de la polyurie et de la déshydration en post-opératoire. Tous les patients ayant reçu 
du méthoxyflurane présentèrent une augmentation de l'acide urique sérique plus grande que chez tout patient servant de contrôle. Aucun de ces patients ne présenta de néphrotoxicité permanente, mais chez un patient, les anomalies persistèrent 68 jours.

Il semble que la lésion rénale associée à l'anesthésie au méthoxyflurane est due à la néphrotoxicité du fluor inorganique. Mazze et associés ont rapporté une augmentation de la concentration du fluor inorganique dans le sérum et l'urine de tous leurs patients anesthésisé au méthoxyflurane, avec le niveau le plus élevé chez les patients présentant des perturbations de la fonction rénale. On observa aussi une augmentation important de l'acide oxalique dans l'urine. Le fluor et l'acide oxalique sont deux produits de biodégradation du méthoxyflurane, le fluor étant probablement responsable de la lésion rénale associée à l’administration du méthoxyflurane ; plusieurs arguments sont en faveur de ce concept; d'abord la corrélation de la perturbation clinique de la fonction rénale et l'augmentation du fluor inorganique dans le sérum ; les effets inhibiteurs puissants de fluor inorganique sus plusieurs systèmes enzymatiques, incluant ceux qui entrent en jeu lors de l'action de l'ADH, et l'insuffisance rénale polyurique chez les rats soumis à une diète riche en fluor comme preuve supplémentaire, Mazze et associés ont récemment produit des insuffisances rénales polyuriques aigues chez des rats en relation avec la dose de méthoxyflurane, et un syndrome similaire à la suite d'injection intrapéritonéale de fluorure sodique.

On doit chercher uné explication à la haute incidence de perturbation de la fonction rénale chez les patients étudiés par Crandell et Mazze. Bien qu'il n'y ait aucun signe clinique dans les études de Mazze et ass. que leurs patients étaient anesthésiés trop profondément, il semble que la dose totale de méthoxyflurane était élevée. Ceci était probablement dû à l'emploi d'induction par inhalation avec omission de barbituriques, de narcotiques et de protoxide d'azote pour des opérations de durée supérieure à 4 heures. Dans une évaluation récente controlée de la fonction rénale chez des patients anesthésiés avec du méthoxyflurane à bas dosage pour chirurgie avec "Bypass" cardioplumonaire, Cousins et ass. n'ont pu mettre en évidence aucune perturbation de la fonction rénale. La concentration moyenne de méthoxyflurane était de $7.78 \pm 1.01 \mathrm{mg}$ pour cent ( $\mathrm{MAC}=13.4 \mathrm{mg}$ pour cent $)$; la durée moyenne de l'administration de méthoxyflurane fut 2 heures et 17 minutes. La concentration moyenne du fluor inorganique dans le sérum fut environ un quart de celle antérieurement rapportée chez les patients symptomatiques cliniquement. Cette étude ainsi que celle citée plus haut chez l'animal indique que la lésion rénale associée à l'administration de méthoxyflurane est un rapport avec le dosage et dépend de la quantité de fluorure produit lors de la dégradation de cet agent anesthésique. Bien que la chirurgie avec "Bypass" cardiopulmonaire représente une situation bien spéciale, les effets d'une augmentation des fluorures inorganiques chez ces patients peuvent ne pas être substantiellement différents de ceux produits chez les patients subissant une chirurgie générale. Il semble qu'une dose faible de méthoxyflurane ne produit qu'une augmentation modérée des fluorures inorganiques qui n'est pas associée à une perturbation de la fonction rénale.

Cependant, il faut être prudent, car plusieurs questions importantes demeurent sans réponse : Est-ce que des variations individuelles dans le métabolisme du 
méthoxyflurane ou une sensibilité exagérée aux fluorures inorganiques résulteront en une toxicité rénale, même avec des doses faibles du méthoxyflurane ? Est-ce que l'induction enzymatique due à l'exposition de substances chimiques variées telles que barbituriques, tranquilisants, insecticides, aérosol ou méthoxyflurane lui-même peut causer une accélération de la production des fluorures inorganiques ? Est-ce qu'une répétition de l'administration de méthoxyflurane cause une augmentation du risque de toxicité due à l'induction enzymatique et à un résidu de fluorures inorganiques? Quelle est la réaction du méthoxyflurane avec d'autres agents thérapeutique potentiellement néphrotoxiques? En rapport avec la dernière question, il y a plusieurs rapports indiquant que la néphrotoxicité du méthoxyflurane et de la tétracycline est additive. De plus, nous avons noté une augmentation de la néphrotoxicité du méthoxyflurane chez les patients recevant de la gentamicine ; et nous avons reproduit ce phénomène chez les animaux en laboratoire.

Les questions les plus importantes sont peut-être les suivantes : Quelle est la limite supérieure d'une dose faible de méthoxyflurane et est-ce que cette limite est la même pour tous les patients ? Seule une recherche minutieuse chez l'humain et l'animal pourra répondre à cette question. En attendant, le clinicien doit être prudent et évaluer les avantages et les désavantages de l'anesthésie au méthoxyflurane avant de la choisir comme agent anesthésique.

Dentscle et ass. ont rapporté un type additionnel de défaillance rénale secondaire à l'anesthésie et à la chirurgie. Ils ont noté une sécrétion inappropriée d'ADH chez les patients âgés subissant une chirurgie majeure et recevant des solutés hypotoniques pendant et après l'opération. Ces patients ont montré une hyponatrémie avec osmolarité sérique basse malgré une excrétion persistante d'urine hypertonique. Cliniquement, ces patients ont développé une variété de symptomes neurologiques diffus allant de l'agitation et la désorientation à une stupeur profonde. L'amélioration a suivi la restriction des fluides.

\section{REFERENCES}

1. Scirmeinfr, G.E. \& Marer, J.F. Toxic nephropathy. Amer. J. Med. 38: 409-499 (1965).

2. Conen, E.N. Metabolism of the volatile anesthetics. Anesthesiology 35: 193-202 (1971).

3. Holaday, D.A., Rudofsky, S., \& Trfuhaft, P.S. The metabolic degradation of methoxyflurane anesthesia. II. Fluoride concentration in nephrotoxicity. J.A.M.A. 214: 91-95 (1971).

4. Mazze, R.I., Trunell, J.R., \& Cousins, M.J. Methoxuflurane metabolism and renal dysfunction: Clinical correlation in man. Anesthesiology 35: 2.47-252 (1971).

5. Burnett, C.H., Bloomberc, E.L., Shortz, G., et al. A comparison of the effects of ether and cyclopropane anesthesia on the renal function of man. J. Pharm. Exp. Ther. 96:380 (1949).

6. IIabif, D.V., Papper, E.M., Firzpatrick, II.F., et al. The renal and hepatic blood flow, glomerular filtration rate, and urinary output of electrolytes during cyclopropane, ether. and thiopental anesthesia, operation, and the immediate postoperative period. Surgery 30 : 241 (1951).

7. Mrles, B.E., DeWardener, H.E., Churchimt-Davidson, II.C., et al. The effect of the renal circulation of pentamethonium bromide during anesthesia. Clin. Sci. 11:73 (1952).

8. Deutsch, S., Pifree, E.C. Jr., \& Vandam, L.D. Cyclopropane effects of renal function in normal man. Anesthesiology 28: 5.47 ( 1967 ).

9. Mazze, R.I., Schwartz, F.D., Slocum, H.C., et al. Renal function during anesthesia and surgery. I. The effects of halothane anesthesia. Anesthesiology 24: 279-284 (1963). 
10. Barry, K.G., MAzze, R.I., \& SChwartz, F.D. Prevention of surgical oliguria and renal hemodynamic suppression by sustained hydration. New Eng. J. Med. 270: 1371 ( 1964 ).

11. Auberger, H. \& Heinrich, J. Methoxyflurane and nierefunktion. Der Anaesthesist 14: 202-264 (1965).

12. Deutsch, S., Bastron, R.D., Pierce, E.C., et al. The effects of anaesthesia with thiopentone, nitrous oxide, narcotics and neuromuscular blocking drugs on renal function in normal man. Brit. J. Anaesth. 41: 807 ( 1969 ).

13. Gonman, H.M. \& Craythonne, N.W.B. The effects of a new neuroleptanalgesic agent (Innovar) on renal function in man. Acta Anaes., Scan. Suppl. 24: 111 (1966).

14. Hayes, M.A., Goldenberg, I.S. Renal effects of anesthesia and operation mediated by endocrines. Anesthesiology 24: 487 (1963).

15. Crandell, W.B., Pappas, S.G., \& Macdonald, A. Nephrotoxicity associated with methoxyflurane anesthesia. Anesthesiology 27: 591 (1966).

16. MAzze, R.I., Shue, G.L., \& JACKson, S.H. Renal dysfunction associated with methoxyflurane anesthesia: a randomized prospective clinical evaluation. J.A.M.A. 216: 278-288 (1971).

17. Crandell, W.B. \& Macdonald, A. Nephropathy associated with methoxyflurane anesthesia. J.A.M.A. 205: 798-799 (1968).

18. MAzze, R.I. \& BARRY, K.G. Prevention of functional renal failure during anesthesia and surgery by sustained hydration and mannitol infusion. Anesth. and Analg. 46: 61-68 ( 1967$)$.

18a. Kennedy, W.F., Sawyer, T.K., Gerbershagen, H.U., et al. Systemic cardiovascular and renal hemodynamic alterations during peridural anesthesia in normal man. Anesthesiology 31: 414-421 (1969).

19. Pezzr, P.J., Frobese, A.S., \& Greenberg, S.R. Methoxyflurane and renal toxicity. Lancet l: 823 (1966).

20. Elkington, S.G., Goffinet, J.A., \& Cons, H.O. Renal and hepatic injury associated with methoxyflurane anesthesia. Ann. Intern. Med. 69: 1229-1236 (1968).

21. Kuzucu, E.Y. Methoxyflurane, tetracycline, and renal failure. J.A.M.A. 211: 1162-1164 $(1970)$.

22. Lapotnte, A. \& Belle-Binda, N. Nephrotoxicite associee au methoxyflurane. Canad. Anaes. Soc. J. 17: 145-156 (1970).

23. Lebowitz, M.H. Nephrogenic diabetes insipidus following methoxyflurane anesthesia: a report of two cases. Anesth. and Analg. 48: 233-236 (1969).

24. Mignault, G., Labrecque, B., \& Hamel, S. Methoxyflurane et nephrotoxicite: etude de la fonction renale de 22 malades anesthesies au methoxyflurane. Canad. Anaesth. Soc. J. 17: 331-340 (1970).

25. Hollenberg, N.K., McDonald, F.D., Cotran, R., et al. Irreversible acute oliguric renal failure: a complication of methoxyflurane anesthesia. New Eng. J. Med. 286: 877-879 (1972).

26. Taves, D.R., Fry, B.W., Freeman, R.B., et al. Toxicity following methoxyflurane anesthesia. II. Fluoride concentration in nephrotoxicity. J.A.M.A. 214: 91-95 (1970).

27. Frascino, J.A., Vanamee, P., \& Rosen, P.P. Renal oxalosis and azotemia after methoxyflurane anesthesia. New Eng. J. Med. 283: 676-679 (1970).

28. VAN DYke, R.A. Metabolism of volatile anesthetics. III. Induction of microsomal dechlorinating and ether-cleaving enzymes. J. Pharmacol. Exp. Ther. 154: 364-369 (1966).

29. Wiseman, A. Effect of inorganic fluoride on enzymes in Handbook of Experimental Pharmacology, Pharmacology of Fluorides. Edited by F.A. Smith. New York, Springer-Verlag, pp. 48-93 (1970).

30. Bond, A.M. \& Murray, M.M. Kidney function and structure in chronic fluorosis. Brit. J. Exp. Path. 33: 168-176 (1952).

31. Cousins, M.J., Nishimura, T.G., \& Mazze, R.I. Renal effects of low-dose methoxyflurane with cardiopulmonary bypass. Anesthesiology 36: 286-292 (1972).

32. Cale, J.O., OArJs, C.R., \& Jenkins, M.T. Hepatic and renal effects of methoxyflurane in dogs. Anesthesiology 23: 248-250 (1967).

33. Вова, A. The effects of methoxyflurane on the renal blood flow of the dog. Anesthesiology $26: 240$ (1965).

34. Bergeron, J.L., Shinabergen, I.H., \& Frederickson, E.L., et al. The effect of methoxyflurane (M) anesthesia on renal tubular handling of water. Clinical Research 16: 59 (1968).

35. Mazze, R.I., Cousins, M.J., \& Kosek, J.C. Strain differences in metabolism and susceptibility to the nephrotoxic effects of methoxyflurane in rats. J. Pharm. \& Exp. Therap. (in press). 
36. Mazze, R.I., Cousins, M.J., \& Kosek, J.C. Dose-related methoxyflurane nephrotoxicity in rats: a biochemical and pathological correlation. Anesthesiology 36: 571-587 (1972).

36a. Kosek, J.C., Mazze, R.I., \& Cousins, M.J. The morphology and pathogenesis of nephrotoxicity following methoxyflurane (Penthrane) anesthesia: An experimental model in rats. Lab. Invest. 27: 575-580 (1972).

37. Cousins, M.J., \& MAZZE, R.I. Etiologic factors in the development of methoxyflurane nephrotoxicity in rats (in preparation).

38. BarR, G.A., Mazze, R.I., Cousins, M.J., \& Kosek, J.C. An animal model for combined methoxyflurane and gentamicin nephrotoxicity. Brit. J. Anaes. (in press).

39. Mazze, R.I. and Cousins, M.J. Combined nephrotoxicity of gentamicin and methoxyflurane anesthesia in man. Brit. J. Anaes. (in press).

40. Cousins, M.J. \& MAzze, R.I. Dose-related nephrotoxicity due to methoxyflurane anesthesia in man. Presented at the Annual Meeting of the American Society of Anesthesiologists, Boston, Massachusetts, October, 1972. 